\section{(A) Check for updates}

Cite this: Dalton Trans., 2019, 48, 8153

Received 3rd April 2019,

Accepted 1st May 2019

DOI: 10.1039/c9dt01418g

rsc.li/dalton

\title{
Mono- and bimetallic amidinate samarium complexes - synthesis, structure, and hydroamination catalysis $\uparrow$
}

\begin{abstract}
Neda Kazeminejad, Luca Münzfeld, Michael T. Gamer and Peter W. Roesky (D) *
In order to investigate the difference between mono- and bimetallic systems in the catalytic hydroamination/cyclization reaction two mono- and bimetallic amidinate samarium catalysts, featuring comparable coordination environments, were synthesized. Both systems comprise two $\left.\left\{\mathrm{N}_{(\mathrm{SiMe}}\right)_{2}\right\}^{-}$leaving groups to minimize the steric influence of the corresponding amidinate ligand. The bimetallic system is based on a bis(amidinate) 4,6-dibenzofuran derivative, while $N, N^{\prime}$-bis(2,6-diisopropylphenyl)benzamidinate was employed as ligand for the monometallic catalyst. For the hydroamination/cyclization reaction five different substrates were investigated. Additionally, kinetic studies were carried out to gain deeper understanding of the mechanism.
\end{abstract}

\section{Introduction}

Amidinates and the closely related guanidinates are a very well established class of ligands, which have been widely used in coordination chemistry. ${ }^{1-5}$ In general, amidinates $\left[\mathrm{RC}\left(\mathrm{NR}^{\prime}\right)_{2}\right]^{-}$ are monoanionic nitrogen-donor ligands, which can be easily accessed by different synthetic routes. Moreover, the steric and electronic properties of amidinates can be tuned by adapting the substituents $\mathrm{R}$ and $\mathrm{R}^{\prime}$.

In lanthanide chemistry, amidinates were introduced about three decades ago by Edelmann et al. ${ }^{6-8}$ Ever since they have emerged as versatile ligands for the synthesis of both di- and trivalent lanthanide complexes. ${ }^{7-13}$ Some of these complexes have also been used for different applications such as homogeneous catalysis, or as precursors for atomic layer deposition (ALD) and metalorganic chemical vapor deposition (MOCVD). ${ }^{7,8,11,14-30}$

Nevertheless bis(amidinates), which were introduced into rare-earth chemistry by Hessen, Teuben et al. about two decades ago, are less common. ${ }^{31}$ Such ligand systems basically contain two amidinate functions, that are linked by a flexible or rigid organic spacer. Initially Teuben used these ligands for the synthesis of monometallic compounds, whereas nowadays linked bis(amidinates) are additionally applied in the synthesis of bimetallic complexes. Trifonov, Shen and others employed

Institut für Anorganische Chemie, Karlsruher Institut für Technologie (KIT), Engesserstr. 15, Geb. 30.45, 76131 Karlsruhe, Germany. E-mail: roesky@kit.edu $\dagger$ Electronic supplementary information (ESI) available: NMR and IR spectra and crystallographic studies. CCDC 1904969-1904970. For ESI and crystallographic data in CIF or other electronic format see DOI: 10.1039/c9dt01418g bis(amidinates) linked by e.g. 1,3-diaminopropane, ${ }^{32-35} \mathrm{o}-, \mathrm{m}$ and $p$-phenylene, ${ }^{36-40}$ pyridinediyl, ${ }^{39,40}$ 1,4-cyclohexene, ${ }^{36}$ naphthalene $\mathrm{e}^{41-44}$ or propyl ${ }^{45}$ for the synthesis of mono- and bimetallic rare-earth complexes.

Aside from f-element chemistry Hagadorn et al. established dibenzofuran and phenanthrene linked bis(amindinates) for aluminium, titanium, and zirconium based complexes. ${ }^{46-49}$

Some of the bimetallic complexes ligated by linked bis(amidinates) have been employed as catalysts. ${ }^{34,36,42,45}$ In general, bimetallic catalysts with both metals in well-defined distance to each other can feature cooperative substrate activation, a highly interesting property for the application in efficient catalytic transformations..$^{50-53}$ On the other hand, it is very challenging to obtain similar bimetallic catalysts together with their monometallic reference systems to study these effects in detail.

Recently, we introduced bis(amidinate) ligands linked by rigid dibenzofuran and phenanthrene backbones into lanthanide chemistry for the first time. The design of this ligand scaffold was inspired by the work of Hagadorn et al. mentioned above. ${ }^{4-49}$ Depending on the ligand scaffold and the lanthanide source, either monometallic complexes or bi- and tetra-metallic macrocycles were obtained. ${ }^{54}$ The mono- and bimetallic systems (A and B) shown in Scheme 1 were used as catalysts in the intramolecular hydroamination reaction and their reactivity (mono vs. dinuclear) was compared. Depending on the nuclearity of the catalyst a difference in kinetics was observed.

Both systems shown in Scheme 1 feature one, respectively two samarium atoms ligated by two amidinate units and one $\left\{\mathrm{N}\left(\mathrm{SiMe}_{3}\right)_{2}\right\}^{-}$leaving group. ${ }^{54}$ Herein, we now report on related 


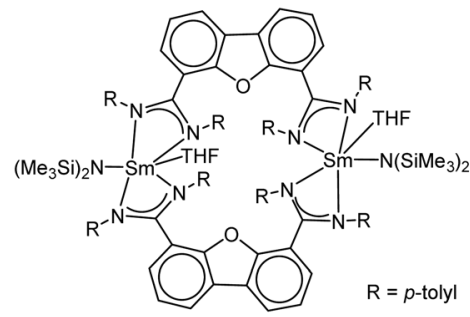

A

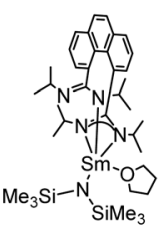

B
Scheme 1 Recently reported mono and bimetallic catalyst for the intramolecular hydroamination reaction. ${ }^{54}$

but more open systems, in which the metal is ligated by one amidinate unit only. Thus, two $\left\{\mathrm{N}\left(\mathrm{SiMe}_{3}\right)_{2}\right\}^{-}$leaving groups can be bound to the central metal ion. For a reasonable comparison in the intramolecular hydroamination catalysis, we attempted to design the ligand framework of the mono- and the linked bis(amidinates) as closely related as possible.

\section{Results and discussion}

\section{Ligands}

Both systems presented in here are literature known. For the synthesis of the bimetallic complexes a bis(amidinate) ligand based on a dibenzofuran backbone, ${ }^{\mathrm{iPr}} \mathrm{L}_{\mathrm{DBF}} \mathrm{H}_{2}$ (Scheme 2), was applied. Following a procedure reported by Hagadorn et al. ${ }^{49}$ dibenzofuran was deprotonated with a slight excess of $n$-butyllithium to give 4,6-dilithiodibenzofuran. Further reaction with di-isopropylcarbodiimid (DIC) and hydrolyzation resulted in the proligand ${ }^{i P r} \mathrm{~L}_{\mathrm{DBF}} \mathrm{H}_{2}$ (Scheme 2). The proligand was characterized by NMR and IR spectroscopy. The data is in agreement with the literature. ${ }^{49}$

For the monometallic complex the proligand $N, N^{\prime}$-bis(2,6diisopropylphenyl)benzamidine $\left({ }^{\text {Dipp }} \mathrm{L}_{\mathrm{Ph}} \mathrm{H}\right)$ was prepared analogue to the literature in a one-pot reaction via the so-called carbodiimide route. ${ }^{55}$ Phenyl lithium was reacted with bis(2,6diisopropylphenyl)carbodiimide in 1:1 molar ratio to give the corresponding lithium salt $\mathrm{Li}\left[{ }^{\mathrm{Dipp}} \mathrm{L}_{\mathrm{Ph}}\right]$. After hydrolysis, the amidine ${ }^{\text {Dipp }} \mathrm{L}_{\mathrm{Ph}} \mathrm{H}$ was obtained (Scheme 3). The NMR data correspond to those in the literature. ${ }^{55}$

\section{Metal complexes}

The synthesis of the desired bimetallic complex $\left[\mathrm{Sm}_{2}\left({ }^{\mathrm{iPr}} \mathrm{L}_{\mathrm{DBF}}\right)\right.$ $\left.\left\{\mathrm{N}\left(\mathrm{SiMe}_{3}\right)_{2}\right\}_{4}\right](\mathbf{1})$ was achieved by an amine elimination reaction. The neutral proligand ${ }^{i P r} \mathrm{~L}_{\mathrm{DBF}} \mathrm{H}_{2}$ was treated in refluxing toluene with the homoleptic amido complex $\left[\mathrm{Sm}\left\{\mathrm{N}\left(\mathrm{SiMe}_{3}\right)_{2}\right\}_{3}\right]$

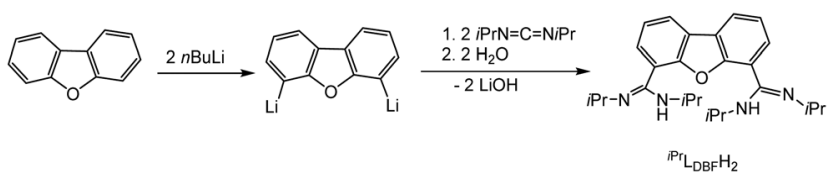

Scheme 2 Synthesis of ${ }^{\mathrm{iPr}} \mathrm{L}_{\mathrm{DBF}} \mathrm{H}_{2}{ }^{49}$

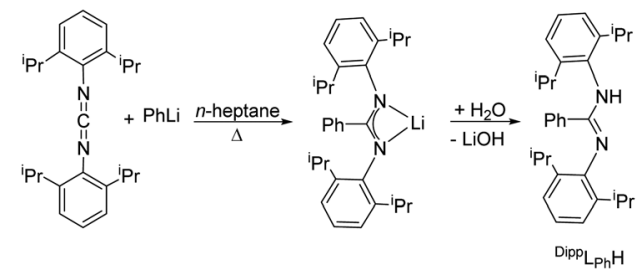

Scheme 3 Synthesis of ${ }^{D i p p} L_{p h} H^{55}$

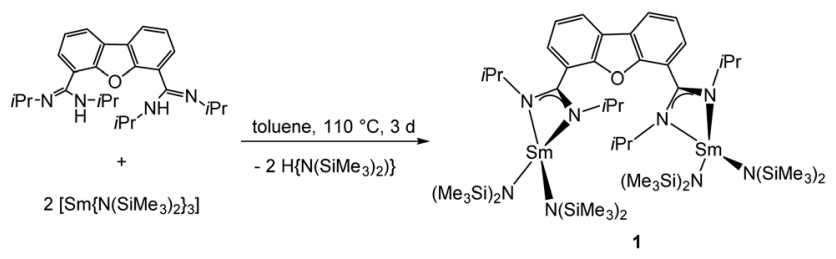

Scheme 4 Synthesis of 1.

in a $1: 1$ stoichiometric ratio for three days (Scheme 4). After workup, compound $\mathbf{1}$ was crystallised from hot toluene to give single crystals suitable for X-Ray diffraction.

Compound 1 crystallizes in the orthorhombic space group I222, with four molecules in the unit cell (Fig. 1). The crystals showed signs of slight twinning but no applicable twin law could be found for the final refinement. As expected, a bimetallic complex, in which two $\left\{\operatorname{Sm}\left\{\mathrm{N}\left(\mathrm{SiMe}_{3}\right)_{2}\right\}_{2}\right\}$ fragments coordinate to each amidinate function, was obtained. A crystallographic $C 2$ axis along the center of the furan ring is observed. The amidinate function coordinates in a slightly asymmetric fashion in a $\kappa^{2}-\left(N, N^{\prime}\right)$ mode to the metal atoms (Sm-N1 2.37(2) $\AA$ and Sm-N2 2.42(2) $\AA$ ). The observed bond distances are somewhat shorter than those in $\mathbf{A}(2.448 \AA) .{ }^{54}$ In total the samarium atoms are four-fold coordinated in a distorted tetrahedral fashion by two nitrogen atoms of the amidinate function and two nitrogen atoms from the $\left\{\mathrm{N}\left(\mathrm{SiMe}_{3}\right)_{2}\right\}^{-}$ groups. The metal-to-metal distance in $\mathbf{1}$ is $8.84 \AA$ and thus $0.6 \AA$ A longer than the metal-to-metal distance in $\mathbf{A}$.

Compound 1 was also characterized by ${ }^{1} \mathrm{H}$ NMR, ${ }^{13} \mathrm{C}\left\{{ }^{1} \mathrm{H}\right\}$ NMR, IR spectroscopy and elemental analysis. The NMR

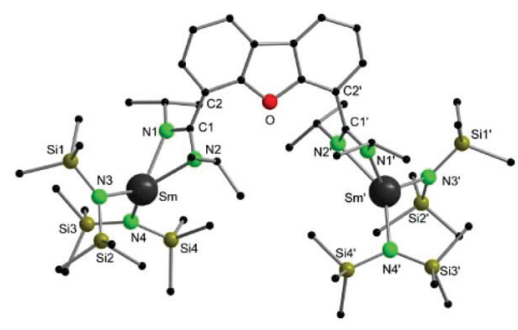

Fig. 1 Molecular structure of 1 in the solid-state. Hydrogen atoms are omitted for clarity. Selected bond lengths [Å], angles [']: Sm-Sm' 8.884, Sm-N1 2.37(2), Sm-N2 2.42 (2), Sm-N3 2.282(14), Sm-N4 2.30 (2), Si1-N3 1.73(2), Si2-N3 1.70(2), Si3-N4 1.68(2), Si4-N4 1.71(2), N1-C1 1.35(2), N2-C1 1.29(2); N1-Sm-N2 55.4(6), N2-C1-N1 115.0(2), N3-Sm-Si4 136.0(5). 


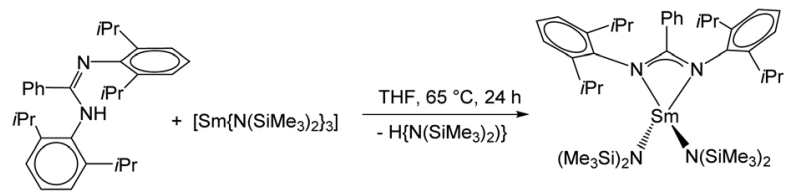

Scheme 5 Synthesis of 2 .

spectra were measured at room temperature in THF for a better resolution. However, due to the paramagnetic nature of the samarium ions some line broadening is observed (Fig. S3 and $\mathrm{S} 4 \dagger$ ).

For accessing a mononuclear complex ligated by only one amidinate ligand, a ligand with a high steric demand of the substituent on the nitrogen atom is needed. Otherwise, product mixtures with a metal to ligand ratio ranging from $1: 1$ up to $1: 3$, are obtained, which are difficult to separate.

The desired complex $\left[\mathrm{Sm}\left({ }^{\mathrm{Dipp}} \mathrm{L}_{\mathrm{Ph}}\right)\left\{\mathrm{N}\left(\mathrm{SiMe}_{3}\right)_{2}\right\}_{2}\right]$ (2) was obtained in a similar synthetic protocol as described above for 1. Reaction of ${ }^{\text {Dipp }} \mathrm{L}_{\mathrm{Ph}} \mathrm{H}$ with a slight excess of $\left[\mathrm{Sm}\left\{\mathrm{N}\left(\mathrm{SiMe}_{3}\right)_{2}\right\}_{3}\right]$ in refluxing $\mathrm{THF}$ resulted in an amine elimination reaction, which gave the monometallic complex 2 in good yields. Single crystals were obtained after recrystallization from hot THF (Scheme 5).

Compound 2 was fully characterized by common analytic techniques and its solid-state structure was established by single crystal X-ray diffraction (Fig. 2). As described above for compound 1, significant line broadening and shifting of resonances is observed due to the paramagnetic character of the samarium ion (Fig. $\mathrm{S} 5 \dagger$ ).

Compound 2 crystallizes in the monoclinic space group $P 2_{1} / n$ with four molecules of 2 and four molecules of THF in the unit cell. The amidinate group coordinates to the metal in a syn-conformation with a $\kappa^{2}-\left(N, N^{\prime}\right)$ mode, whereas the Sm-N1/

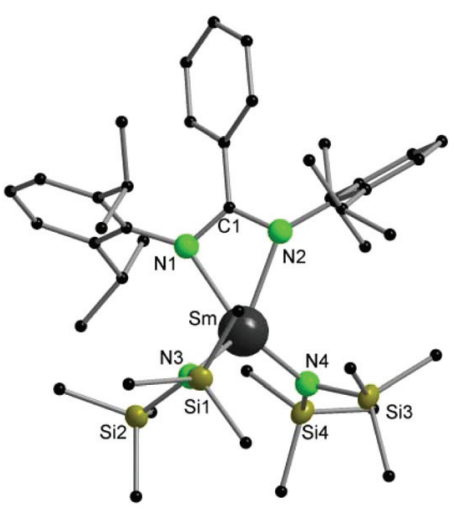

Fig. 2 Molecular structure of 2 in the solid-state. Hydrogen atoms and solvent molecules are omitted for clarity. Selected bond lengths [Å], angles [ ${ }^{\circ}$ ]: Sm-N1 2.421(3), Sm-N2 2.415(3), Sm-N3 2.306(3), Sm-N4 2.297(3), Si1-N3 1.727(3), Si2-N3 1.705(4), Si3-N4 1.715(3), Si4-N4 1.728 (4), N1-C1 1.330(5), N2-C1 1.354(5); N1-Sm-N2 55.56(11), N3-Sm-N4 121.49(13), N1-C1-N2 114.2(4).
2 bond distances are 2.421(3) A and 2.415(3) Å, respectively. As observed in 1, the samarium atom is four fold coordinated in a distorted tetrahedral fashion by two nitrogen atoms of the amidinate function and two nitrogen atoms from the $\left\{\mathrm{N}\left(\mathrm{SiMe}_{3}\right)_{2}\right\}^{-}$groups. The $\mathrm{Sm}-\mathrm{N}$ bond distances to the $\left\{\mathrm{N}\left(\mathrm{SiMe}_{3}\right)_{2}\right\}^{-}$groups are Sm-N3 2.306(3) Å and Sm-N4 2.297(3) A.

Due to the similar binding modes of the ligands and coordination polyhedrons observed in compounds $\mathbf{1}$ and 2 as well as utilization of the same leaving groups $\left(\left\{\mathrm{N}\left(\mathrm{SiMe}_{3}\right)_{2}\right\}^{-}\right)$, we consider compounds $\mathbf{1}$ and $\mathbf{2}$ as a suitable couple to compare mono- and bimetallic complexes in hydroamination catalysis.

\section{Catalytic hydroamination cyclization reaction}

Hydroamination is the addition of ammonia or an organic amine nitrogen-hydrogen bond to a carbon-carbon double or triple bond in one step. The advantage of this synthetic route is the straightforward access to amines without any side-products. In contrast, most of the classical amine synthesis require multistep reactions and are accompanied by the formation of side-products. Although the catalytic hydroamination reaction is thermodynamically feasible under normal conditions, the high activation barrier hampers its use in synthesis. Since the pioneering work of Marks et al. ${ }^{56-60}$ in the early 1990ies a large number of homogeneous catalysts for the hydroamination reaction have been established. About two decades ago Livinghouse et al. and our group could show that homoleptic lanthanide amides $\left[\mathrm{Ln}\left\{\mathrm{N}\left(\mathrm{SiMe}_{3}\right)_{2}\right\}_{3}\right]$ are active as catalysts in the catalytic hydroamination reaction but coligands are beneficial in many cases. ${ }^{61,62}$ The progress in this area over the last decade has been reviewed extensively. ${ }^{56,63-89}$ On the other hand bimetallic catalysis in hydroamination reactions was not investigated in detail.

In our previous contribution, we reported on the hydroamination cyclization catalyzed by compounds $\mathbf{A}$ and $\mathbf{B} .^{54}$ In the intramolecular hydroamination reactions, both of the complexes give excellent yields. It was demonstrated that the monometallic complex B shows faster conversion and different kinetics than the bimetallic system $\mathbf{A}$, e.g. for the formation of the five-membered rings Ib and IIb (Table 1), zero-order kinetics with respect to the substrate concentration were observed for the bimetallic catalyst A, while first order kinetics with respect to the substrate concentration were determined for the monometallic catalyst $\mathbf{B}$.

Herein, we compare now the more open bi- and monometallic catalysts 1 and 2 , which both have two $\left\{\mathrm{N}\left(\mathrm{SiMe}_{3}\right)_{2}\right\}^{-}$ leaving groups. The catalytic hydroamination experiments were carried out under rigorous anaerobic conditions in $\mathrm{C}_{6} \mathrm{D}_{6}$ at different temperatures with catalyst loadings of $2 \mathrm{~mol} \%$ for the bimetallic system 1 and 4 mol\% for the monometallic catalyst 2 , in order to have the same substrate to metal ratio. The conversion was followed by ${ }^{1} \mathrm{H}$ NMR spectroscopy using ferrocene as an internal standard. To investigate the substrate dependency five different substrates were employed, of which four are amino alkenes (Table 1, Ia-IVa) and one is an amino alkyne (Table 1, Va). 
Table 1 Intramolecular hydroamination using 1 and 2 as catalysts

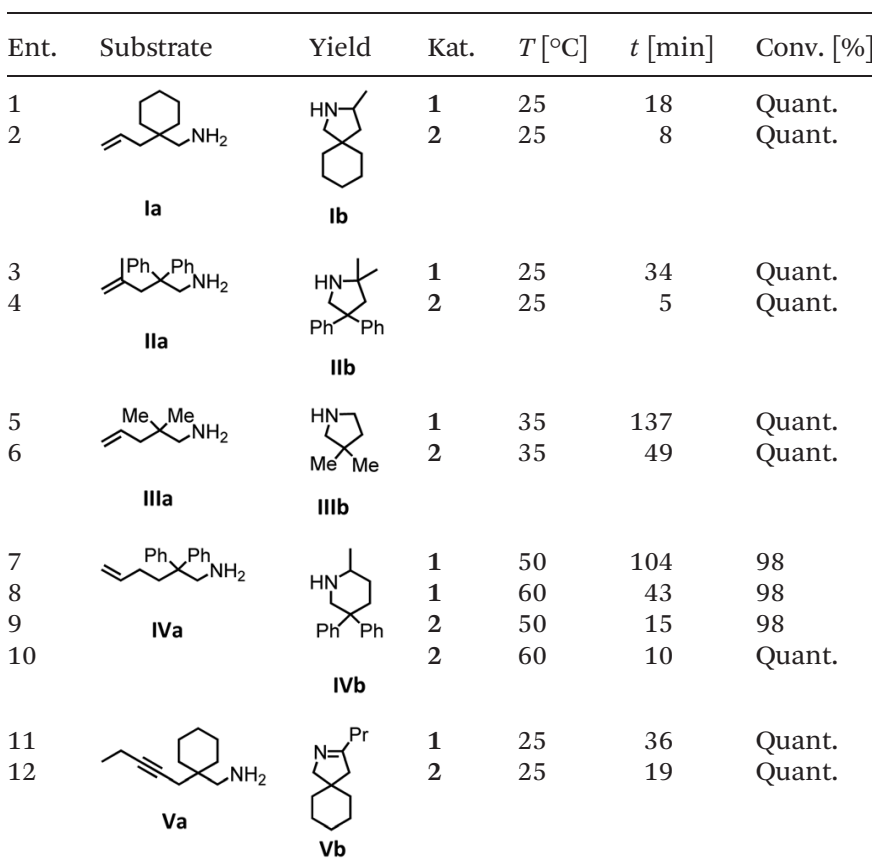

Conditions: Complex 1: (10 mg, 2 mol\%); complex 2: (10 mg, 4 mol\%), $\mathrm{C}_{6} \mathrm{D}_{6}$, calculated by ${ }^{1} \mathrm{H}$ NMR spectroscopy, using ferrocene as the internal standard.

All substrates were converted in (almost) quantitative yields, as shown in Table 1 . The differences in reactivity of the substrates can be explained by the Thorpe-Ingold effect, which means that bulky substituents at the $\beta$-position to the amino group favor the cyclization. ${ }^{90-95}$

In general, compared to the bis(amidinate) complexes $\mathbf{A}$ and $\mathbf{B}$, compounds $\mathbf{1}$ and $\mathbf{2}$ show faster conversions for all substrates depicted in Table 1 . Obviously the more open coordination sphere of the mono(amidinate) complexes $\mathbf{1}$ and $\mathbf{2}$ is beneficial. In addition it was shown by Rodríguez et al. that a lutetium catalyst with two leaving groups can bind two cyclized substrate molecules simultaneously. ${ }^{96}$ In general, the monometallic catalyst 2 shows faster conversions than the bimetallic system 1. We do not have a straightforward explanation for this observation. However, since four substrate molecules can bind to the samarium ions in $\mathbf{1}$, there may be a diffusion limit to reach this concentration. In this case separating the metals into two catalytic active molecules may be an advantage.

To get some understanding of the mechanism, kinetic studies of the hydroamination cyclization of the aminoalkenes IIIa and IVa by using $\mathbf{1}$ and $\mathbf{2}$ as catalyst were carried out. All reactions were monitored in situ by ${ }^{1} \mathrm{H}$ NMR spectroscopy at different temperatures. The full data is shown in the ESI. $\dagger$ Substrate IIIa was reacted at $35^{\circ} \mathrm{C}$ and $60^{\circ} \mathrm{C}$ by using 1 as catalyst. Since 2 shows a higher catalytic activity, the reactions were monitored at $15^{\circ} \mathrm{C}, 25^{\circ} \mathrm{C}$, and $35^{\circ} \mathrm{C}$. In each case, a linear dependency between $\ln$ [substrate] vs. time was observed indicating that the reaction is first order in substrate concentration (see Fig. 3 and S9-S13†).

In contrast to the previously reported catalysts $\mathbf{A}$ and $\mathbf{B}$ neither different kinetics for the same substrate nor any temperature dependency of the kinetic order were observed by comparing a mono vs. a bimetallic system.
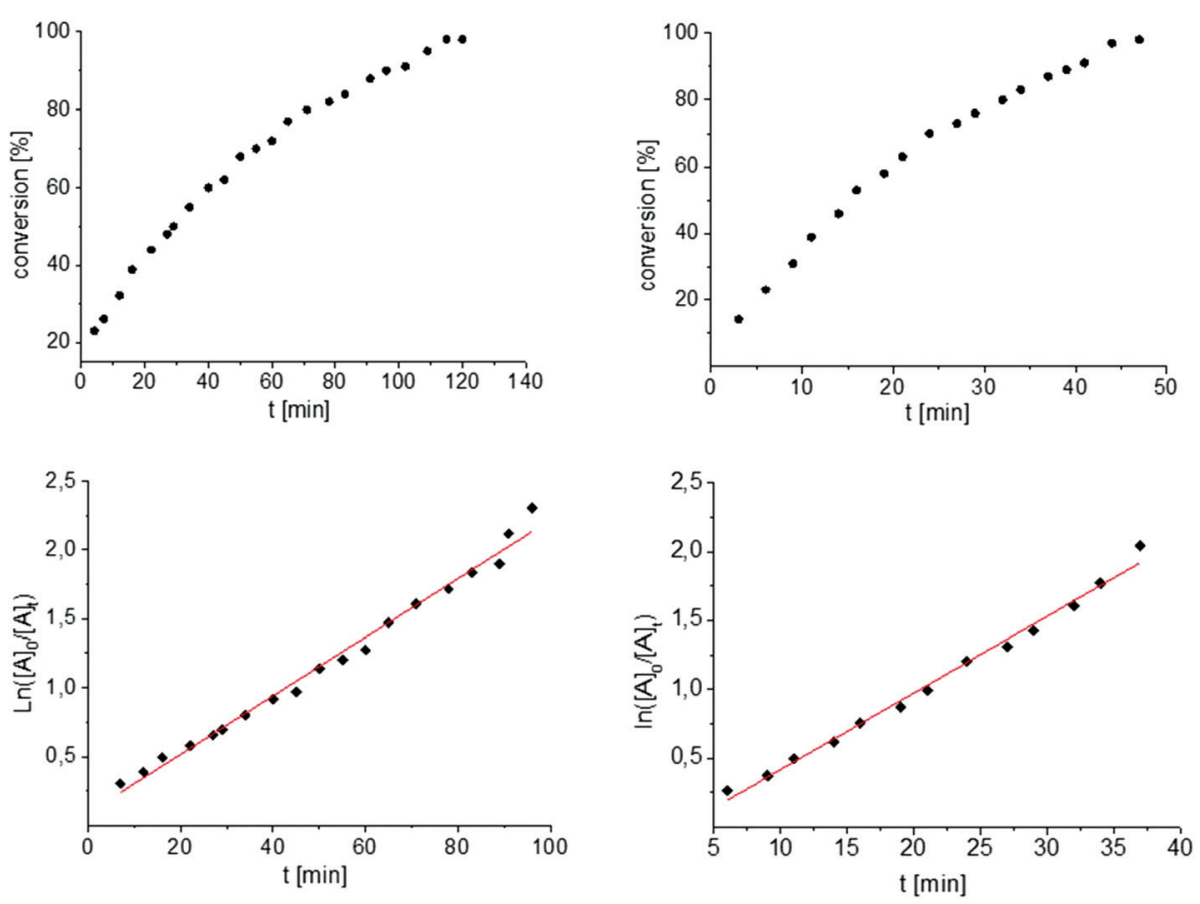

Fig. 3 Conversion of Illa with 1 (left) and 2 (right) at $35^{\circ} \mathrm{C}$. First order kinetics in respect to the substrate concentration for both reactions were observed (Table 1, entries 5 and 6, see also Fig. S9 and S13 $)$ ). For the determination of the kinetic the final phase (from about $90 \%$ conversion) was cut off. 

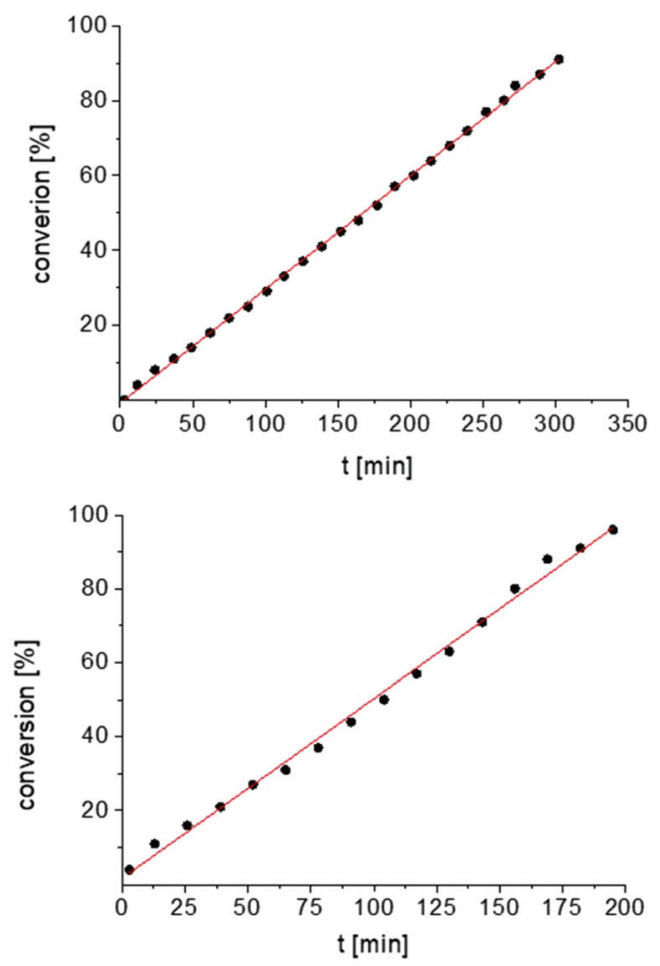

Fig. 4 Conversion of IVa with 1 at $40^{\circ} \mathrm{C}$ (top) and 2 at $30^{\circ} \mathrm{C}$ (bottom). Zero order kinetics with respect to the substrate concentration for both reactions were observed (see also Fig. S14 and S17†).

In addition, the cyclization leading to a six-membered ring was investigated in detail. Substrate IVa was reacted at 40, 50, and $60^{\circ} \mathrm{C}$ by using 1 as catalyst and at 30, 35, and $50{ }^{\circ} \mathrm{C}$ with the faster system 2 as catalyst (Fig. 4 and S14-S29†). In each case, a zero order kinetics in substrate concentration was determined.

In contrast to catalysts $\mathbf{A}$ and $\mathbf{B}$, compounds $\mathbf{1}$ and $\mathbf{2}$ always show the same kinetic order for the same substrate. This may be an effect of the more remote metal centers in the bimetallic catalyst 1 , which means that both catalytic centers operate independently of each other.

\section{Summary}

In summary, we have prepared a mono and a bimetallic complex with one amidinate ligand and two $\left\{\mathrm{N}\left(\mathrm{SiMe}_{3}\right)_{2}\right\}^{-}$ leaving groups. Both systems show similar kinetics for the conversions of aminoalkenes to five and six membered rings. Although both systems have a similar coordination sphere, the monometallic system is the more efficient catalyst. Since it is known that both leaving groups of the metal can be substituted by two substrates, up to four substrate molecules can bind to the bimetallic system. We suggest that the lower performance of the bimetallic catalyst may be caused by diffusion control of the substrate coordination.

\section{Experimental $^{97}$}

\section{General procedures}

All air- and water-sensitive materials were prepared under an argon or a nitrogen atmosphere on a Schlenk line or in a glovebox. THF was distilled from potassium metal under nitrogen before use. Toluene, $n$-heptane and $n$-pentane were dried using an MBraun solvent purification system (SPS-800). Deuterated solvents were purchased from Eurisotop (99 atom\% D) and were dried and stored under vacuum with $\mathrm{Na} / \mathrm{K}$ alloy. All other chemicals were purchased and used without further purification. NMR spectra were recorded on a Bruker Avance II $300 \mathrm{MHz}$ or Avance III $400 \mathrm{MHz}$ NMR spectrometer. Elemental analyses were carried out on an Elementar Vario Micro Cube. IR spectra were performed on a Bruker TENSOR 37 spectrometer via the attenuated total reflection method (ATR). $\left[\mathrm{Sm}\left\{\mathrm{N}\left(\mathrm{SiMe}_{3}\right)_{2}\right\}_{3}\right]$ was prepared using a modified procedure of Bradley et al. ${ }^{98}$ We found, that using 2.90 equivalents of $\mathrm{K}\left\{\mathrm{N}\left(\mathrm{SiMe}_{3}\right)_{2}\right\}$ instead of 3 equivalents $\mathrm{Li}\left\{\mathrm{N}\left(\mathrm{SiMe}_{3}\right)_{2}\right\}$ gave good yields without the formation of 'ate' complexes or the need for additional purification. ${ }^{54}{ }^{i P r} \mathrm{~L}_{\mathrm{DBF}} \mathrm{H}_{2}$ was prepared according to a literature procedure. ${ }^{49}$

$\boldsymbol{N}, \boldsymbol{N}^{\prime}$-Bis(2,6-diisopropylphenyl)benzamidinate. Bis-(2,6diiso-propylphenyl)carbodiimide $(1.99 \mathrm{~g}, 5.5 \mathrm{mmol})$ was dissolved in $n$-heptane (50 mL). Phenyl lithium (1.9 M, $2.9 \mathrm{ml}$, $5.5 \mathrm{mmol}$ ) was added at room temperature to form a white suspension. After stirring the reaction mixture for $2 \mathrm{~h}, \mathrm{H}_{2} \mathrm{O}$ $(50 \mathrm{ml})$ was added to protonate the ligand. The organic phase was separated, dried over sodium sulfate and then under vacuum. Afterwards the residue was washed with cold $n$-pentane and dried under vacuum to give a white powder. Yield: $2.16 \mathrm{~g}, 89 \%$.

$\left[\mathrm{Sm}_{2}\left({ }^{\mathrm{iPr}} \mathbf{L}_{\mathrm{DBF}}\right)\left\{\mathbf{N}\left(\mathrm{SiMe}_{3}\right)_{2}\right\}_{4}\right]$ (1). Toluene (15 mL) was condensed at $-78{ }^{\circ} \mathrm{C}$ onto a mixture of $\left[\mathrm{Sm}\left\{\mathrm{N}\left(\mathrm{SiMe}_{3}\right)_{2}\right\}_{3}\right](400 \mathrm{mg}$, $0.63 \mathrm{mmol}$ ) and ${ }^{\mathrm{iPr}} \mathrm{L}_{\mathrm{DBF}} \mathrm{H}_{2}(133 \mathrm{mg}, 0.32 \mathrm{mmol})$. The reaction mixture was heated under reflux for $72 \mathrm{~h}$. After cooling to room temperature, the solvent was removed under reduced pressure. The residue was washed with $n$-pentane $(10 \mathrm{~mL})$. The remaining solid was recrystallized from hot toluene to obtain yellow single crystals suitable for X-ray diffraction. Yield (based of single crystals): $205 \mathrm{mg}$ (48\%). Anal. Calcd (\%) for $\left[\mathrm{C}_{50} \mathrm{H}_{106} \mathrm{~N}_{8} \mathrm{OSi}_{8} \mathrm{Sm}_{2}\right]$ (1360.85): C, 44.13, H, 7.85, N, 8.23. Found: C, 43.31, H, 7.55, N, 8.06. ${ }^{1} \mathrm{H}$ NMR (d d $_{8}$ THF, $300 \mathrm{MHz}$, $298 \mathrm{~K}): \delta(\mathrm{ppm})=9.94\left(\mathrm{~d},{ }^{3} J_{\mathrm{H}, \mathrm{H}}=7.3 \mathrm{~Hz}, 2 \mathrm{H}, A r\right), 9.59\left(\mathrm{~d},{ }^{3} J_{\mathrm{H}, \mathrm{H}}\right.$ $=7.7 \mathrm{~Hz}, 2 \mathrm{H}, A r), 8.69\left(\mathrm{t},{ }^{3} J_{\mathrm{H}, \mathrm{H}}=7.3 \mathrm{~Hz}, 2 \mathrm{H}, A r\right), 4.37(\mathrm{~s}, 4 \mathrm{H}$, $\left.\mathrm{CHCH}_{3}\right), 1.22\left(\mathrm{~s}, 12 \mathrm{H}, \mathrm{CHCH}_{3}\right), 0.05\left(\mathrm{~s}, 12 \mathrm{H}, \mathrm{CHCH}_{3}\right),-2.35(\mathrm{~s}$, $\left.72 \mathrm{H}, \mathrm{SiCH}_{3}\right) .{ }^{13} \mathrm{C}\left\{{ }^{1} \mathrm{H}\right\} \mathrm{NMR}\left(\mathrm{d}_{8}-\mathrm{THF}, 75 \mathrm{MHz}, 298 \mathrm{~K}\right): \delta(\mathrm{ppm})=$ $157.9\left(\mathrm{ArCN}_{2}\right), 132.4(\mathrm{Ar}), 129.8(\mathrm{Ar}), 128.9(\mathrm{Ar}), 126.6(\mathrm{Ar})$, 126.3 (Ar), $124.0(A r), 51.7\left(\mathrm{CHCH}_{3}\right), 28.0\left(\mathrm{CHCH}_{3}\right), 23.4$ $\left(\mathrm{CHCH}_{3}\right), 2.7\left(\mathrm{SiCH}_{3}\right) \mathrm{ppm}$. IR (ATR): $\left(\tilde{v} / \mathrm{cm}^{-1}\right)=3660(\mathrm{vw})$, 2956 (m), 2867 (w), 1641 (w), 1603 (w), 1472 (s), 1416 (m), 1336 (m), 1247 (s), 1178 (s), 1132 (w), 1054 (vw), 1001 (s), 931 (m), 879 (m), 830 (s), 786 (s), 754 (vs), 668 (m), 569 (m), 462 (w).

$\left[\mathbf{S m}\left({ }^{\text {Dipp }} \mathbf{L}_{\mathbf{P h}}\right)\left\{\mathbf{N}\left(\mathrm{SiMe}_{3}\right)_{2}\right\}_{2}\right]$ (2). THF $(20 \mathrm{~mL})$ was condensed at $-78{ }^{\circ} \mathrm{C}$ onto a mixture of $\left[\mathrm{Sm}\left\{\mathrm{N}\left(\mathrm{SiMe}_{3}\right)_{2}\right\}_{3}\right](394 \mathrm{mg}$, $0.624 \mathrm{mmol})$ and ${ }^{\mathrm{Dipp}} \mathrm{L}_{\mathrm{Ph}} \mathrm{H}(267 \mathrm{mg}, 0.606 \mathrm{mmol})$. The reaction 
was heated under reflux for $24 \mathrm{~h}$. After cooling to room temperature, the solvent was removed under reduced pressure. The residue was washed with $5 \mathrm{ml}$ of $n$-pentane and recrystallised from hot THF to give yellow single crystals suitable for X-ray diffraction. Yield (based of single crystals): $338 \mathrm{mg}$ (61\%). Anal. Calcd (\%) for $\left[\mathrm{C}_{43} \mathrm{H}_{75} \mathrm{~N}_{4} \mathrm{Si}_{4} \mathrm{Sm}\right]$ (910.80): C, 56.71, H, 8.30, N, 6.15. found: C, 56.93, H, 8.18, N, 5.94. ${ }^{1} \mathrm{H}$ NMR $\left(\mathrm{C}_{6} \mathrm{D}_{6}\right.$, $300 \mathrm{MHz}, 298 \mathrm{~K}): \delta(\mathrm{ppm})=9.89\left(\mathrm{~d},{ }^{3} J_{\mathrm{H}, \mathrm{H}}=7.6 \mathrm{~Hz}, 2 \mathrm{H}, A r\right)$, $7.78\left(\mathrm{t},{ }^{3} J_{\mathrm{H}, \mathrm{H}}=7.5 \mathrm{~Hz}, 2 \mathrm{H}, A r\right), 7.64\left(\mathrm{t},{ }^{3} J_{\mathrm{H}, \mathrm{H}}=7.4 \mathrm{~Hz}, 1 \mathrm{H}, A r\right)$, $7.07\left(\mathrm{t},{ }^{3} J_{\mathrm{H}, \mathrm{H}}=7.7 \mathrm{~Hz}, 2 \mathrm{H}, A r\right), 6.79\left(\mathrm{~d},{ }^{3} J_{\mathrm{H}, \mathrm{H}}=7.7 \mathrm{~Hz}, 4 \mathrm{H}, A r\right)$, 1.44 (s, 12H, $\mathrm{CHCH}_{3}$ ), 0.77 (br. s, $\left.4 \mathrm{H} \mathrm{CHCH}_{3}\right), 0.27(\mathrm{~s}, 12 \mathrm{H}$, $\left.\mathrm{CHCH}_{3}\right),-3.79\left(\mathrm{~s}, 36 \mathrm{H}, \mathrm{SiCH}_{3}\right) .{ }^{13} \mathrm{C}\left\{{ }^{1} \mathrm{H}\right\} \mathrm{NMR}\left(\mathrm{C}_{6} \mathrm{D}_{6}, 75 \mathrm{MHz}\right.$, $298 \mathrm{~K}): \delta(\mathrm{ppm})=147.5\left(\mathrm{ArCN}_{2}\right), 140.6(\mathrm{Ar}), 137.6(\mathrm{Ar}), 134.9$ (Ar), 131.1 (Ar), 128.8 (Ar), 125.3 (Ar), 123.8 (Ar), $28.9\left(\mathrm{CHCH}_{3}\right)$, $24.7\left(\mathrm{CHCH}_{3}\right), 24.0\left(\mathrm{CHCH}_{3}\right), 0.4\left(\mathrm{SiCH}_{3}\right)$ (one of the expected aromatic carbon resonances is overlapped by the $\mathrm{C}_{6} \mathrm{D}_{6}$ signal). IR (ATR): $\left(\tilde{v} / \mathrm{cm}^{-1}\right)=3364(\mathrm{w}), 3062(\mathrm{w}), 2958(\mathrm{~s}), 2869(\mathrm{w})$, 1614 (s), 1575 (m), 1451 (s), 1433 (s), 1386 (m), 1354 (s), $1322(\mathrm{~m}), 1249(\mathrm{~s}), 1103(\mathrm{w}), 1052(\mathrm{w}), 930$ (vs), $881(\mathrm{~m})$, 834 (vs), 764 (vs), 694 (s), 605 (w), 555 (w), 477 (w), 429 (w).

Typical procedure for the intramolecular hydroamination. In a glovebox, a NMR tube was charged with the corresponding catalyst ((2 mol\%) 1 and (4 mol\%) 2) and ferrocene (as internal standard, $10 \mathrm{~mol} \%) . \mathrm{C}_{6} \mathrm{D}_{6}$ was condensed at $-196{ }^{\circ} \mathrm{C}$ into the mixture. After dissolving the catalyst in benzene and freezing it at $-196^{\circ} \mathrm{C}$, the substrate was injected into the mixture. The NMR tube was flame sealed at $-196{ }^{\circ} \mathrm{C}$ under vacuum. The sample mixture was melted and mixed by shacking the sample tube just before insertion into the NMR machine $\left(t_{0}\right)$. The ratio between the reactant and the product was calculated by comparison of the corresponding signals. The substrates $C$-(1-allylcyclohexyl)-methylamine (Ia), ${ }^{99}$ 1-amino-2,2-diphenyl-4-methylpent-4-ene (IIa), ${ }^{100}$ 2,2-dimethylpent-4-en-1-amine (IIIa), ${ }^{99}$ 2,2diphenyl-5-hexenyl-1-amine (IVa), ${ }^{100} \quad$ [1-(pent-2-ynyl)-cyclohexyl]methanamine $(\mathbf{V a})^{99}$ were synthesized according to literature procedures. The ${ }^{1} \mathrm{H}$ NMR data of 3-methyl-2-aza-spiro-[4.5] decane (Ib), ${ }^{101}$ 2,2-dimethyl-4,4-diphenylpyrroli-dine (IIb), ${ }^{100}$ 2,5-dimethylpyrrolidine (IIIb), ${ }^{99}$ 2-methyl-5,5-diphenylpiperidine (IVb), ${ }^{100}$ 3-propyl-2-azaspiro[4.5]dec-2-ene (Vb), ${ }^{99}$ agree with those reported in the literature.

\section{X-Ray crystallographic studies of 1-2}

A suitable crystal was covered in mineral oil (Aldrich) and mounted on a glass fiber or a mylar loop. The crystal was transferred directly to the cold stream of a STOE IPDS 2 diffractometer.

All structures were solved by using the program SHELXS/ $\mathrm{T}^{102,103}$ using Olex2. ${ }^{104}$ The remaining non-hydrogen atoms were located from successive difference Fourier map calculations. The refinements were carried out by using full-matrix least-squares techniques on $F^{2}$ by using the program SHELXL. ${ }^{102,103}$ In each case, the locations of the largest peaks in the final difference Fourier map calculations, as well as the magnitude of the residual electron densities, were of no chemical significance. Positional parameters, hydrogen atom parameters, thermal parameters, bond distances and angles have been deposited as ESI. $\dagger$

Crystal data. $\mathrm{C}_{50} \mathrm{H}_{106} \mathrm{~N}_{8} \mathrm{OSi}_{8} \mathrm{Sm}_{2}, \quad M_{\mathrm{r}}=1360.84$, orthorhombic, $I 222$ (no. 23), $a=10.5585(7) \AA, b=20.1286(14) \AA, c=$ 34.786(3) ̊, $V=7393.0(10) \AA^{3}, T=100 \mathrm{~K}, Z=4, \mu\left(\mathrm{MoK}_{\alpha}\right)=1.74$, 17973 reflections measured, 9097 unique $\left(R_{\text {int }}=0.0945\right)$ which were used in all calculations. The final $w R_{2}$ was 0.2681 (all data) and $R_{1}$ was $0.0984(I>2(I))$.

Crystal data 2. $\mathrm{C}_{47} \mathrm{H}_{83} \mathrm{~N}_{4} \mathrm{OSi}_{4} \mathrm{Sm}, M_{\mathrm{r}}=982.88$, monoclinic, $P 2_{1} / n$ (no. 14), $a=12.0107(7) \AA$, $b=26.4912(18) \AA, c=17.3028$ (10) $\AA, \beta=95.898(5)^{\circ}, V=5476.2(6) \AA^{3}, T=210 \mathrm{~K}, Z=4$, $\mu\left(\mathrm{MoK}_{\alpha}\right)=1.20,27921$ reflections measured, 10159 unique $\left(R_{\text {int }}=0.0431\right)$ which were used in all calculations. The final $\mathrm{w} R_{2}$ was 0.0836 (all data) and $R_{1}$ was $0.0386(I>2(I)$ ).

Crystallographic data (excluding structure factors) for the structures reported in this paper have been deposited with the Cambridge Crystallographic Data Centre as a supplementary publication no. CCDC-1904969-1904970.†

\section{Conflicts of interest}

There are no conflicts to declare.

\section{Acknowledgements}

Financial support by the DFG-funded transregional collaborative research center SFB/TRR 88 "Cooperative Effects in Homo and Heterometallic Complexes (3MET)” project B3 is gratefully acknowledged.

\section{Notes and references}

1 P. C. Junk and M. L. Cole, Chem. Commun., 2007, 15791590.

2 F. T. Edelmann, in Adv. Organomet. Chem, ed. F. H. Anthony and J. F. Mark, Academic Press, 2008, vol. 57, pp. 183-352.

3 A. A. Trifonov, Coord. Chem. Rev., 2010, 254, 1327-1347.

4 F. T. Edelmann, in Adv. Organomet. Chem, ed. F. H. Anthony and J. F. Mark, Academic Press, 2013, vol. 61, pp. 55-374.

5 F. T. Edelmann, in Adv. Organomet. Chem, ed. F. H. Anthony and J. F. Mark, Academic Press, 2008, vol. 57, pp. 183-352.

6 M. Wedler, F. Knösel, U. Pieper, D. Stalke, F. T. Edelmann and H.-D. Amberger, Chem. Ber., 1992, 125, 2171-2181.

7 F. T. Edelmann, Chem. Soc. Rev., 2009, 38, 2253-2268.

8 F. T. Edelmann, Chem. Soc. Rev., 2012, 41, 7657-7672.

9 F. T. Edelmann, Angew. Chem., Int. Ed. Engl., 1995, 34, 2466-2488.

10 F. T. Edelmann, Top. Curr. Chem., 1996, 179, 113-148.

11 F. T. Edelmann, Struct. Bonding, 2010, 137, 109-164.

12 F. T. Edelmann, J. Alloys Compd., 1994, 207-208, 182-188. 
13 J. R. Hagadorn and J. Arnold, Organometallics, 1996, 15, 984-991.

14 B. S. Lim, A. Rahtu and R. G. Gordon, Nat. Mater., 2003, 2, 749-754.

15 A. P. Milanov, R. A. Fischer and A. Devi, Inorg. Chem., 2008, 47, 11405-11416.

16 J. Paivasaari, C. L. Dezelah, IV, D. Back, H. M. El-Kaderi, M. J. Heeg, M. Putkonen, L. Niinisto and C. H. Winter, J. Mater. Chem., 2005, 15, 4224-4233.

17 S. Bambirra, M. W. Bouwkamp, A. Meetsma and B. Hessen, J. Am. Chem. Soc., 2004, 126, 9182-9183.

18 V. Y. Rad'kov, G. G. Skvortsov, D. M. Lyubov, A. V. Cherkasov, G. K. Fukin, A. S. Shavyrin, D. Cui and A. A. Trifonov, Eur. J. Inorg. Chem., 2012, 2289-2297.

19 L. Zhang, M. Nishiura, M. Yuki, Y. Luo and Z. Hou, Angew. Chem., Int. Ed., 2008, 47, 2642-2645.

20 S. Bambirra, D. van Leusen, A. Meetsma, B. Hessen and J. H. Teuben, Chem. Commun., 2003, 522-523.

21 Y. Luo, Y. Yao, Q. Shen, J. Sun and L. Weng, J. Organomet. Chem., 2002, 662, 144-149.

22 C. Villiers, P. Thuéry and M. Ephritikhine, Eur. J. Inorg. Chem., 2004, 4624-4632.

23 E. A. Bijpost, R. Duchateau and J. H. Teuben, J. Mol. Catal. A: Chem., 1995, 95, 121-128.

24 A. A. Trifonov, in Olefin Upgrading Catalysis by Nitrogenbased Metal Complexes I: State-of-the-art and Perspectives, ed. J. Campora and G. Giambastiani, Springer Netherlands, Dordrecht, 2011, pp. 119-152.

25 S. Bambirra, H. Tsurugi, D. van Leusen and B. Hessen, Dalton Trans., 2006, 1157-1161.

26 S. Bambirra, M. W. Bouwkamp, A. Meetsma and B. Hessen, J. Am. Chem. Soc., 2004, 126, 9182-9183.

27 S. Ge, A. Meetsma and B. Hessen, Organometallics, 2008, 27, 3131-3135.

28 A. A. Trifonov, Rare-Earth Metal Complexes Supported by Nitrogen-Containing Ligands in Olefin Polymerization, in Olefin Upgrading Catalysis by Nitrogen-based Metal Complexes I. ed. J. Campora and G. Giambastiani, Catalysis by Metal Complexes, Springer Netherlands, 2011, vol. 34, pp. 119-152.

29 I. V. Basalov, O. S. Yurova, A. V. Cherkasov, G. K. Fukin and A. A. Trifonov, Inorg. Chem., 2016, 55, 12361244.

30 L. Zhang, M. Nishiura, M. Yuki, Y. Luo and Z. Hou, Angew. Chem., 2008, 120, 2682-2685.

31 S. Bambirra, A. Meetsma, B. Hessen and J. H. Teuben, Organometallics, 2001, 20, 782-785.

32 J. Wang, H. Sun, Y. Yao, Y. Zhang and Q. Shen, Polyhedron, 2008, 27, 1977-1982.

33 J. Wang, J. Li, F. Xu and Q. Shen, Adv. Synth. Catal., 2009, 351, 1363-1370.

34 W. Li, M. Xue, F. Xu, J. Tu, Y. Zhang and Q. Shen, Dalton Trans., 2012, 41, 8252-8260.

35 J. Tu, W. Li, M. Xue, Y. Zhang and Q. Shen, Dalton Trans., 2013, 42, 5890-5901.

36 J. Yang, P. Xu and Y. Luo, Chin. J. Chem., 2010, 28, 457-462.
37 A. O. Tolpygin, A. S. Shavyrin, A. V. Cherkasov, G. K. Fukin and A. A. Trifonov, Organometallics, 2012, 31, 5405-5413.

38 G. G. Skvortsov, G. K. Fukin, S. Y. Ketkov, A. V. Cherkasov, K. A. Lyssenko and A. A. Trifonov, Eur. J. Inorg. Chem., 2013, 4173-4183.

39 A. O. Tolpygin, A. V. Cherkasov, G. K. Fukin and A. A. Trifonov, Inorg. Chem., 2014, 53, 1537-1543.

40 G. G. Skvortsov, A. O. Tolpygin, G. K. Fukin, J. Long, J. Larionova, A. V. Cherkasov and A. A. Trifonov, Eur. J. Inorg. Chem., 2017, 4275-4284.

41 M. V. Yakovenko, A. V. Cherkasov, G. K. Fukin, D. Cui and A. A. Trifonov, Eur. J. Inorg. Chem., 2010, 3290-3298.

42 M. V. Yakovenko, A. A. Trifonov, E. Kirillov, T. Roisnel and J.-F. Carpentier, Inorg. Chim. Acta, 2012, 383, 137-142.

43 C. Wang, X. Zhang, M. Xue, Y. Zhang and Q. Shen, Dalton Trans., 2013, 42, 7009-7018.

44 M. V. Yakovenko, N. Y. Udilova, T. A. Glukhova, A. V. Cherkasov, G. K. Fukin and A. A. Trifonov, New J. Chem., 2015, 39, 1083-1093.

45 X. Yu, M. Li, J. Hong, X. Zhou and L. Zhang, Chem. - Eur. J., 2019, 25, 2569-2576.

46 J. R. Hagadorn, Chem. Commun., 2001, 2144-2145.

47 J. R. Hagadorn and M. J. McNevin, Organometallics, 2003, 22, 609-611.

48 J. R. Hagadorn, M. J. McNevin, G. Wiedenfeld and R. Shoemaker, Organometallics, 2003, 22, 4818-4824.

49 B. Clare, N. Sarker, R. Shoemaker and J. R. Hagadorn, Inorg. Chem., 2004, 43, 1159-1166.

50 M. Delferro and T. J. Marks, Chem. Rev., 2011, 111, 24502485.

51 P. Buchwalter, J. Rosé and P. Braunstein, Chem. Rev., 2015, 115, 28-126.

52 M. Trincado and H. Grützmacher, in Cooperative Catalysis, Wiley-VCH Verlag GmbH \& Co. KGaA, 2015, pp. 67-110.

53 J. P. McInnis, M. Delferro and T. J. Marks, Acc. Chem. Res., 2014, 47, 2545-2557.

54 N. Kazeminejad, D. Munzel, M. T. Gamer and P. W. Roesky, Chem. Commun., 2017, 53, 1060-1063.

55 J. Hong, L. Zhang, K. Wang, Z. Chen, L. Wu and X. Zhou, Organometallics, 2013, 32, 7312-7322.

56 S. Hong and T. J. Marks, Acc. Chem. Res., 2004, 37, 673686.

57 M. R. Gagne, L. Brard, V. P. Conticello, M. A. Giardello, C. L. Stern and T. J. Marks, Organometallics, 1992, 11, 2003-2005.

58 M. R. Gagne, C. L. Stern and T. J. Marks, J. Am. Chem. Soc., 1992, 114, 275-294.

59 M. A. Giardello, V. P. Conticello, L. Brard, M. R. Gagné and T. J. Marks, J. Am. Chem. Soc., 1994, 116, 1024110254.

60 L. Huang, M. Arndt, K. Gooßen, H. Heydt and L. J. Gooßen, Chem. Rev., 2015, 115, 2596-2697.

61 Y. K. Kim, T. Livinghouse and J. E. Bercaw, Tetrahedron Lett., 2001, 42, 2933-2935.

62 M. R. Bürgstein, H. Berberich and P. W. Roesky, Chem. Eur. J., 2001, 7, 3078-3085. 
63 P. W. Roesky and T. E. Müller, Angew. Chem., Int. Ed., 2003, 42, 2708-2710.

64 K. C. Hultzsch, Org. Biomol. Chem., 2005, 3, 1819-1824.

65 X. Han and R. A. Widenhoefer, Angew. Chem., Int. Ed., 2006, 45, 1747-1749.

66 I. Aillaud, J. Collin, J. Hannedouche and E. Schulz, Dalton Trans., 2007, 5105-5118.

67 J.-J. Brunet, N.-C. Chu and M. Rodriguez-Zubiri, Eur. J. Inorg. Chem., 2007, 4711-4722.

68 A. V. Lee and L. L. Schafer, Eur. J. Inorg. Chem., 2007, 2245-2255.

69 R. Severin and S. Doye, Chem. Soc. Rev., 2007, 36, 1407-1420.

70 T. Andrea and M. S. Eisen, Chem. Soc. Rev., 2008, 37, 550567.

71 T. E. Müller, K. C. Hultzsch, M. Yus, F. Foubelo and M. Tada, Chem. Rev., 2008, 108, 3795-3892.

72 R. Dorta, in Iridium Complexes in Organic Synthesis, WileyVCH Verlag GmbH \& Co. KGaA, 2009, pp. 145-172.

73 G. Zi, Dalton Trans., 2009, 9101-9109.

74 A. N. Duncan and R. A. Widenhoefer, Synlett, 2010, 419-422.

75 K. D. Hesp and M. Stradiotto, J. Am. Chem. Soc., 2010, 132, 18026-18029.

76 T. Li, J. Jenter and P. W. Roesky, Struct. Bonding, 2010, 137, 165-228.

77 A. L. Reznichenko and K. C. Hultzsch, in Chiral Amine Synthesis, Wiley-VCH Verlag GmbH \& Co. KGaA, 2010, pp. 341-375.

78 J. G. Taylor, L. A. Adrio and K. K. Hii, Dalton Trans., 2010, 39, 1171-1175.

79 Z. Guofu, J. Organomet. Chem., 2011, 696, 68-75.

80 J. Jenter, A. Lühl, P. W. Roesky and S. Blechert, J. Organomet. Chem., 2011, 696, 406-418.

81 T. Li, S. Schulz and P. W. Roesky, Chem. Soc. Rev., 2012, 41, 3759-3771.

82 J. Hannedouche and E. Schulz, Chem. - Eur. J., 2013, 19, 4972-4985.

83 N. Nishina and Y. Yamamoto, Top. Organomet. Chem., 2013, 43, 115-143.

84 A. Reznichenko and K. Hultzsch, Top. Organomet. Chem., 2013, 43, 51-114.

85 R. Manzano, T. Wurm, F. Rominger and A. S. K. Hashmi, Chem. - Eur. J., 2014, 20, 6844-6848.
86 W. Yang and A. S. K. Hashmi, Chem. Soc. Rev., 2014, 43, 2941-2955.

87 A. Arcadi, Top. Heterocycl. Chem., 2016, 46, 53-85.

88 T. Li, J. Wiecko and P. W. Roesky, in Zinc-catalyzed hydroamination reactions, ed. S. Enthaler and X. Wu, Wiley-VCH Verlag GmbH \& Co. KGaA, 2015, pp. 83-118.

89 A. L. Reznichenko and K. C. Hultzsch, Org. React., 2016, 88, 1-554.

90 M. R. Gagne and T. J. Marks, J. Am. Chem. Soc., 1989, 111, 4108-4109.

91 Y. Li, P.-F. Fu and T. J. Marks, Organometallics, 1994, 13, 439-440.

92 Y. Li and T. J. Marks, J. Am. Chem. Soc., 1996, 118, 92959306.

93 M. E. Jung and G. Piizzi, Chem. Rev., 2005, 105, 17351766.

94 A. L. Reznichenko, F. Hampel and K. C. Hultzsch, Chem. Eur. J., 2009, 15, 12819-12827.

95 M. R. Gagne, C. L. Stern and T. J. Marks, J. Am. Chem. Soc., 1992, 114, 275-294.

96 A. Otero, A. Lara-Sánchez, C. Nájera, J. Fernández-Baeza, I. Márquez-Segovia, J. A. Castro-Osma, J. Martínez, L. F. Sánchez-Barba and A. M. Rodríguez, Organometallics, 2012, 31, 2244-2255.

97 N. Kazeminejad, Dissertation, Karlsruhe, Institute of Technology, 2017.

98 D. C. Bradley, J. S. Ghotra and F. A. Hart, J. Chem. Soc., Dalton Trans., 1973, 1021-1023.

99 M. Rastätter, A. Zulys and P. W. Roesky, Chem. - Eur. J., 2007, 13, 3606-3616.

100 M. R. Crimmin, M. Arrowsmith, A. G. M. Barrett, I. J. Casely, M. S. Hill and P. A. Procopiou, J. Am. Chem. Soc., 2009, 131, 9670-9685.

101 J.-S. Ryu, G. Y. Li and T. J. Marks, J. Am. Chem. Soc., 2003, 125, 12584-12605.

102 G. Sheldrick, Acta Crystallogr., Sect. A: Found. Crystallogr., 2008, 64, 112-122.

103 G. Sheldrick, Acta Crystallogr., Sect. C: Struct. Chem., 2015, 71, 3-8.

104 O. V. Dolomanov, L. J. Bourhis, R. J. Gildea, J. A. K. Howard and H. Puschmann, J. Appl. Crystallogr., 2009, 42, 339-341. 